\title{
PENGOLAHAN HASIL BUDIDAYA TANAMAN RIMPANG DENGAN TEKNIK VERTIKULTUR DEMI MENDUKUNG EKONOMI KREATIF MASYARAKAT RAWAMANGUN JAKARTA TIMUR
}

\author{
Rizal Koen Asharo, Reni Indrayanti, Rizky Priambodo, Pinta Omas Pasaribu, \\ Vina Rizkawati, Hilda Arsyah Eka Putri, Patimah Hannum, Amelia Anjani \\ Program Studi Biologi, Fakultas Matematika dan Ilmu Pengetahuan Alam, \\ Universitas Negeri Jakarta
}

Email: koenindo@gmail.com

\begin{abstract}
Narrow house yards and little green open area in Rawamangun, Pulogadung District, East Jakarta cause people to be less interested in farming culture. Therefore, innovation is needed to manipulate the narrow land as a green area in the hope of growing public interest in plant cultivation, namely through verticulture techniques. One of the plants that are suitable for cultivation in a narrow area and at the same time has many benefits for the community directly is a family medicinal plant. Among the existing family medicinal plants, rhizome plants are plants that are easy to grow and are in great demand because they have many health benefits such as ginger, aromatic ginger, and turmeric. From the harvest, the resulting rhizomes can be processed into useful products as well as high economic value such as rhizome powder, candied rhizomes, and jamu. The purpose of this community service is to convey information about verticulture techniques for rhizome cultivation as well as processing techniques for rhizome cultivation into products of high economic value. Submission of information is carried out by means of lectures, discussions, and demonstrations of direct practice of cultivating rhizomes in narrow yards using verticulture techniques. Evaluation of the program's success is carried out by post-test to participants after lectures, discussions, and practices. This program is considered successful because of the increase in basic knowledge of rhizome cultivation techniques with post test scores above 60 and the practice activities are going well. Processing of rhizome cultivation into products of high economic value such as rhizome powder, candied rhizome, and jamu has also been successfully carried out. All participants showed high enthusiasm during hands-on practice. It is hoped that the processed rhizome cultivation can be commercialized so that it can support the economy of the Rawamangun community.
\end{abstract}

Keywords: creative economy; Rawamangun; rhizome plants; verticulture technique

\begin{abstract}
Abstrak
Halaman rumah yang sempit dan sedikit lahan terbuka hijau di Rawamangun, Kecamatan Pulogadung, Jakarta Timur menyebabkan masyarakat kurang meminati budaya bertanam. Oleh karenanya dibutuhkan inovasi untuk memanipulasi lahan yang sempit tersebut sebagai area hijau dengan harapan dapat menumbuhkan minat masyarakat untuk budidaya tanaman yaitu melalui teknik vertikultur. Salah satu tanaman yang cocok dibudidayakan di lahan sempit sekaligus memiliki banyak manfaat bagi masyarakat secara langsung adalah tanaman obat keluarga. Di antara tanaman obat keluarga yang ada, tanaman rimpang adalah tanaman yang mudah ditanam dan banyak diminati karena memiliki banyak manfaat bagi kesehatan seperti jahe, kencur, dan kunyit. Dari hasil panen, rimpang yang dihasilkan bisa diolah menjadi produk yang bermanfaat sekaligus bernilai ekonomi tinggi seperti bubuk rimpang, manisan rimpang, dan jamu. Tujuan pengabdian kepada masyarakat ini adalah menyampaikan informasi mengenai teknik
\end{abstract}


vertikultur untuk budidaya tanaman rimpang sekaligus teknik pengolahan hasil budidaya tanaman rimpang menjadi produk bernilai ekonomi tinggi. Penyampaian informasi dilakukan dengan metode ceramah, diskusi, dan demonstrasi praktik langsung budidaya tanaman rimpang di lahan pekarangan sempit dengan teknik vertikultur. Evaluasi keberhasilan program dilakukan dengan post test kepada peserta setelah dilakukan ceramah, diskusi, dan praktik. Program ini tergolong berhasil karena adanya peningkatan pengetahuan dasar mengenai teknik budidaya tanaman rimpang dengan nilai post test di atas 60 dan kegiatan praktik berlangsung dengan baik. Pengolahan hasil budidaya tanaman rimpang menjadi produk bernilai ekonomi tinggi seperti bubuk rimpang, manisan rimpang, dan jamu juga berhasil dilakukan. Seluruh peserta menunjukkan antusiasme yang tinggi pada saat melakukan praktik langsung. Diharapkan hasil olahan budidaya tanaman rimpang dapat dikomersilkan sehingga dapat mendukung perekonomian masyarakat Rawamangun.

Kata Kunci: ekonomi kreatif; Rawamangun; tanaman rimpang; teknik vertikultur

\section{PENDAHULUAN}

Ekonomi kreatif berhasil membuat perekonomian Indonesia lebih tangguh karena telah membantu menciptakan lapangan kerja sehingga mampu menyerap tenaga kerja melalui produksi produk kreatif. Pemerintah Indonesia sejak tahun 2009 sudah menetukan tahun 2009 adalah Tahun Ekonomi Kreatif. Adanya instruksi Presiden RI Nomer 6 Tahun 2009 mengenai Pengembangan Ekonomi Kreatif dapat dijadikan acuan untuk penggiat usaha ekonomi kreatif dalam meningkatkan kegiatan ekonomi kreatif. Kemudian dengan berubahnya kementerian Pariwisata menjadi Kementerian Pariwisata dan Ekonomi Kreatif berada di bawah Kementerian Perdagangan, Kementrian Perdagangan menindaklanjuti Inpres Nomer 6 Tahun 2009 tersebut dengan Rencana Pembangunan Ekonomi Kreatif Tahun 2009-2025 (Marlinah, 2017). Ekonomi kreatif menjadikan sumber daya manusia sebagai modal utama suatu pembangunan yang bersumber dari ide, gagasan dan pemikiran, dan diharapkan sumber daya manusia ini di masa depan mampu mentransformasikan barangbarang yang bernilai rendah menjadi barang-barang yang berkualitas dan dapat dipasarkan.

Kegiatan ekonomi kreatif merupakan salah satu usaha untuk menaikkan pamasukan rumah tangga secara halal. Salah satu kegiatan ekonomi kreatif yang bisa dilakukan yaitu melalui budidaya tanaman obat keluarga. Tanaman obat keluarga adalah tanaman yang dapat ditanam di pekarangan, pekarangan, ladang atau kebun yang memiliki khasiat untuk mengobati penyakit tertentu. Masyarakat seringkali menggunakan tanaman obat keluarga yang sudah terkenal sebagai obat untuk menyembuhkan beberapa penyakit, baik itu penyakit yang disebabkan oleh perubahan cuaca atau penyakit lainnya (Harefa, 2020). Diantara tanaman obat keluarga yang ada, tanaman rimpang adalah tanaman yang paling banyak dikenal serta dimanfaatkan oleh masyarakat. Contoh tanaman rimpang diantaranya adalah jahe, kunyit, dan kencur. Masing-masing tanaman rimpang memiliki manfaatnya sendiri untuk mengobati penyakit karena kandungan senyawa kimia juga berbedabeda diantara tanaman rimpang. 
Saat ini masyarakat perkotaan kurang menyadari pentingnya budidaya tanaman obat keluarga, terutama tanaman rimpang, yang dapat digunakan untuk mengobati beberapa penyakit yang diderita oleh mereka sendiri dan keluarga. Hal tersebut terjadi dikarenakan adanya beberapa faktor, diantaranya adalah ruang hidup yang terbatas, sehingga kurangnya lahan terbuka untuk budidaya tanaman rimpang. Seringkali sarana pengetahuan untuk budidaya tanaman rimpang juga kurang, sehingga penerapan budidaya tanaman rimpang belum merata di masyarakat perkotaan, sehingga keberadaan kampus di Indonesia diharapkan dapat mendukung pelaksanaan program pemerintah terkait budidaya dan pemanfaatan tanaman rimpang, walaupun hal ini dibatasi oleh minimnya lahan terbuka (Asharo, et al., 2021).

Bagi warga yang tidak memiliki cukup ruang terbuka di area sekitar rumahnya, tanaman rimpang tetap bisa ditanam dengan teknik vertikultur. Pada teknik vertikultur, tanaman akan ditanam pada pot yang disusun secara vertikal. Teknik vertikultur merupakan sistem penghijauan yang sangat cocok dan direkomendasikan untuk daerah perkotaan dengan lahan pekarangan yang terbatas atau sempit. Teknik vertikultur ini dapat menghasilkan banyak tanaman rimpang sekaligus hanya dengan bidang vertikal dinding rumah, tergantung jenis dan kebutuhan tanaman rimpang.

Wilayah Kelurahan Rawamangun, Kecamatan Pulogadung, Jakarta Timur tidak memiliki lahan terbuka yang cukup sehingga minim penghijauan (Pasaribu, et al., 2020). Budidaya dan pemanfaatan tanaman, terutama tanaman obat keluarga, juga masih sangat kurang diminati. Akibatnya, dengan kondisi seperti itu, masyarakat cenderung mengabaikan pentingnya penggunaan tanaman obat keluarga (Asharo, et al., 2021). Salah satu upaya yang dapat dilakukan untuk membantu pelaksanaan program pemerintah terkait pemanfaatan tanaman obat keluarga adalah melalui penyelenggaraan kegiatan Tri Dharma Perguruan Tinggi melalui bentuk kegiatan pengabdian kepada masyarakat (PKM). Masyarakat sekitar kampus dirasa perlu untuk dikaitkan dengan kegiatan tersebut. Hal ini dinilai penting karena kedekatan lokasi antara kampus Universitas Negeri Jakarta dengan wilayah Kelurahan Rawamangun sehingga tersedia kesempatan untuk melakukan implementasi keilmuan langsung kepada masyarakat melalui program PKM. Kegiatan PKM tentang budidaya tanaman obat keluarga telah dilakukan oleh Asharo, et al di awal tahun 2021, sehingga pada tahun ini kegiatan PKM pengolahan hasil budidaya tanaman obat keluarga dengan fokus tanaman rimpang dirasa perlu untuk disampaikan juga kepada masyarakat. Banyak jenis produk yang dapat diperkenalkan kepada masyarakat dalam mengolah hasil budidaya tanaman rimpang, diantaranya serbuk rimpang, manisan rimpang, dan jamu. Diharapkan produk-produk tersebut dapat dibuat secara mandiri oleh masyarakat dan dilanjutkan dengan komersialisasi 
produk oleh masyarakat sehingga dapat meningkatkan nilai ekonomi masyarakat Rawamangun, Kecamatan Pulogadung, Jakarta Timur.

\section{TINJAUAN LITERATUR}

Pemahaman masyarakat lokal dalam upaya pemanfaatan sumber daya tumbuhan akan sangat berperan dalam melestarikan keanekaragaman hayati dan upaya domestikasi tumbuhan (Kandari et al., 2012). Pengetahuan masyarakat tentang pemanfaatan sumber daya tumbuhan dapat diamati melalui apotek hidup. Apotek hidup adalah istilah penggunaan lahan yang ditanami oleh tanaman berkhasiat obat tradisional (Syarif et al., 2011). Pekarangan rumah merupakan petak terbuka yang terletak di sekitar lingkungan perumahan. Pekarangan rumah merupakan tempat yang sangat cocok untuk dijadikan apotek hidup bagi tanaman obat (Nurmayulis dan Hermita, 2015).

Lahan pekarangan rumah memiliki potensi apabila dikelola secara optimal dan terencana. Lahan pekarangan rumah dapat memberikan manfaat dalam menunjang kebutuhan gizi keluarga sekaligus untuk keindahan (estetika) (Rauf, et al., 2013). Lebih lanjut Suryani, et al. (2017) menyatakan bahwa budidaya tanaman obat di perkotaan memiliki peran penting dalam menjamin pasokan sumber daya tanaman obat berkesinambungan untuk penduduk kota. Di perkotaan, kendala yang dihadapi dalam upaya pemanfaatan lahan pekarangan adalah keterbatasan luas lahan. Dengan semakin mahalnya harga lahan di perkotaan, kepemilikan lahan pekarangan menjadi sangat terbatas. Salah satu teknik budidaya tanaman obat yang dapat diterapkan pada lahan terbatas adalah budidaya tanaman obat dengan teknik vertikultur. Vertikultur merupakan teknik bercocok tanam diruang/lahan sempit dengan memanfaatkan bidang vertikal sebagai tempat bercocok tanam yang dilakukan secara bertingkat.

Tanaman obat keluarga adalah tanaman yang ditanam di rumah yang berkhasiat sebagai obat Tanaman obat dapat tergolong bumbu masak atau rempah-rempah, tanaman pagar, tanaman buah atau tanaman pekarangan, dan yang paling sering dikenal adalah dari golongan tanaman rimpang (Saktiawan dan Atmiasri, 2017). Dalam ilmu botani, rizom atau rimpang (rhizome) adalah modifikasi batang tanaman yang tumbuh di bawah permukaan tanah dan dapat menghasilkan tunas dan akar baru dari ruas-ruasnya. Suku temu-temuan (Zingiberaceae) merupakan contoh kelompok tumbuhan yang biasa dipakai untuk mendeskripsikan organ rimpang. Rimpang biasanya memiliki fungsi tambahan seperti batang, yang paling umum adalah penyimpanan produk metabolisme tertentu (metabolit). Rimpang menyimpan banyak minyak atsiri dan alkaloid yang memiliki sifat obat. Rimpang tumbuh dan menjadi cadangan makanan (biasanya dalam bentuk pati) yang bisa disebut sebagai umbi rimpang.

Beberapa jenis tanaman rimpang seperti jahe, kunyit dan kencur diketahui mengandung komponen antioksidan. 
Jahe banyak dimanfaatkan untuk bahan pangan fungsional karena mengandung senyawa polifenol berupa gingerol dan shogaol yang berperan sebagai antioksidan (Palupi dan Widyaningsih , 2015). Gingerol dan shogaol yang merupakan senyawa fenolik dan berperan sebagai antioksidan (Palupi dan Widyaningsih, 2015). Tinggi rendahnya antioksidan jahe dipengaruhi oleh jenis jahe, umur panen, dan kondisi jahe baik segar atau kering (Hernani dan Winarti, 2011). Rimpang kencur mempunyai kandungan kimia antara lain minyak atsiri 2,4-3,9\% yang terdiri dari etil parametoksi sinamat (30\%), kamfer, orneol, sineol, dan penta dekana. Adanya kandungan etil parametoksi sinamat dalam kencur yang merupakan senyawa turunan sinamat. Kandungan utama di dalam rimpang kunyit terdiri dari minyak atsiri, kurkumin, resin, oleoresin, desmetoksikurkumin, dan bidesmetoksikurkumin, damar, gom, lemak, protein, kalsium, fosfor dan besi. Zat warna kuning (kurkumin) dimanfaatkan sebagai pewarna untuk makanan manusia dan ternak. Komponen utama yang terpenting dalam rimpang kunyit adalah kurkuminoid dan minyak atsiri. Kandungan kimia minyak atsiri kunyit terdiri dari ar-tumeron, $\alpha$ dan $\beta$-tumeron, tumerol, $\alpha$-atlanton, $\beta$ kariofilen, linalol, 1,8 sineol. Kandungan kurkumin rimpang kunyit rata rata $10,92 \%$ yang terdiri atas senyawa kurkumin dan keturunannya, dan mempunyai aktivitas berspektrum luas, diantaranya antibakteri, antioksidan, dan antihepatotoksik (Shan dan Iskandar, 2018).
Dari banyaknya kandungan senyawa bermanfaat yang ada pada rimpang jahe, kunyit, dan kencur, peluang untuk dikonversi menjadi produk olahan yang bernilai tambah sangatlah memungkinkan. Pengembangan produk olahan dari tanaman rimpang dapat meningkatkan nilai tambah melalui diversifikasi produk primer (rimpang) menjadi produk sekunder (simplisia, ekstrak). Berdasarkan Departemen Pertanian RI (2007), pengolahan rimpang menjadi produk sekunder mampu meningkatkan nilai tambah sebesar 7-15 kali. Contoh produk sekunder dari rimpang diantaranya serbuk rimpang, manisan rimpang, dan jamu.

\section{METODE PELAKSANAAN}

\section{Tempat dan Waktu}

Program PKM ini ditujukan kepada masyarakat Kelurahan Rawamangun, Jakarta Timur yang dilaksanakan di bulan Oktober 2021. Program PKM ini berlokasi di RW 03 Kelurahan Rawamangun, Jakarta Timur, yang berjarak $\pm 1 \mathrm{~km}$ dari Universitas Negeri Jakarta.

\section{Khalayak Sasaran}

kepada masyarakat Kelurahan Rawamangun, Jakarta Timur dengan jumlah peserta yang terdaftar hadir dari awal hingga akhir kegiatan berjumlah 12 orang yang berusia di atas 17 tahun. Jumlah peserta memang sengaja kami batasi tidak lebih dari 30 orang (sudah termasuk tim pengabdi) dikarenakan pelaksanaan program PKM ini 
bertepatan dengan masa pandemi COVID-19 yang mana seluruh warga Indonesia sedang dihimbau oleh pemerintah untuk tetap tinggal di dalam rumah.

\section{Metode Pengabdian}

Metode alih teknologi yang dilakukan pada kegiatan PKM ini adalah ceramah, diskusi, praktik langsung budidaya tanaman rimpang, serta bimbingan dan pendampingan teknis. Seluruh kegiatan tentunya sudah dirancang agar dapat tetap dilaksanakan sesuai protokol kesehatan yang berlaku. Ceramah dilakukan saat acara sosialisasi berlangsung di RW 03 Kelurahan Rawamangun, Jakarta Timur. Sosialisasi langsung kepada masyarakat mencakup tiga materi yaitu: jenis dan karakteristik tanaman rimpang, cara budidaya tanaman rimpang dengan menggunakan teknik vertikultur, pengolahan hasil budidaya tanaman rimpang sebagai produk bernilai ekonomi tinggi, diantaranya bubuk rimpang, manisan rimpang, dan jamu. Produk dikemas menarik sehingga dapat menambah nilai jual dan peluang bisnis. Diskusi dilakukan setelah ceramah selesai dilakukan. Demonstrasi praktik langsung meliputi tahapan persiapan media tanam vertikultur, penanaman tanaman rimpang diantaranya jahe, kunyit, dan kencur, serta pembuatan produk hasil budidaya tanaman rimpang. Selanjutnya peserta diminta untuk mengisi lembar post test yang berfungsi untuk menguji kepemahaman peserta terhadap materi yang sudah diterima. Hasil post test ini juga ditujukan sebagai indikator keberhasilan kegiatan. Sesusai sosialisasi dan praktik, peserta membawa tiga jenis tanaman rimpang untuk dibudidaya di pekarangan masingmasing dengan metode vertikultur. Bimbingan dan pendampingan teknis dilakukan selama satu bulan setelah penanaman dilakukan. Secara garis besar, alur kegiatan dapat dilihat pada gambar 1.

\section{Indikator Keberhasilan}

Kegiatan PKM dikatakan berhasil jika terdapat peningkatan pengetahuan dan keterampilan peserta tentang tiga materi sosialisasi, yaitu: jenis dan karakteristik tanaman rimpang, cara budidaya tanaman rimpang dengan menggunakan teknik vertikultur, pengolahan hasil budidaya tanaman rimpang sebagai produk bernilai ekonomi tinggi, diantaranya bubuk rimpang, manisan rimpang, dan jamu. Peningkatan pengetahuan dapat ditinjau dari hasil post test yang menunjukkan rata-rata nilai lebih dari 60. Evaluasi ketrampilan dilakukan pada saat demonstrasi praktik langsung. Peserta diminta memperhatikan dan menirukan proses pembuatan media tanam, penanaman, dan pemeliharaan beberapa jenis tanaman rimpang yaitu jahe, kunyit, dan kencur. Peserta yang berhasil membuat media tanam metode vertikultur maka akan dianggap mampu melakukan ketrampilan budidaya tanaman rimpang melalui teknik vertikultur dengan baik. Selanjutnya, peserta yang berhasil membuat produk olahan hasil budidaya tanaman rimpang berupa serbuk rimpang, manisan rimpang, dan jamu, maka akan dianggap mampu melakukan keterampilan 
pengolahan hasil budidaya tanaman rimpang dengan baik.

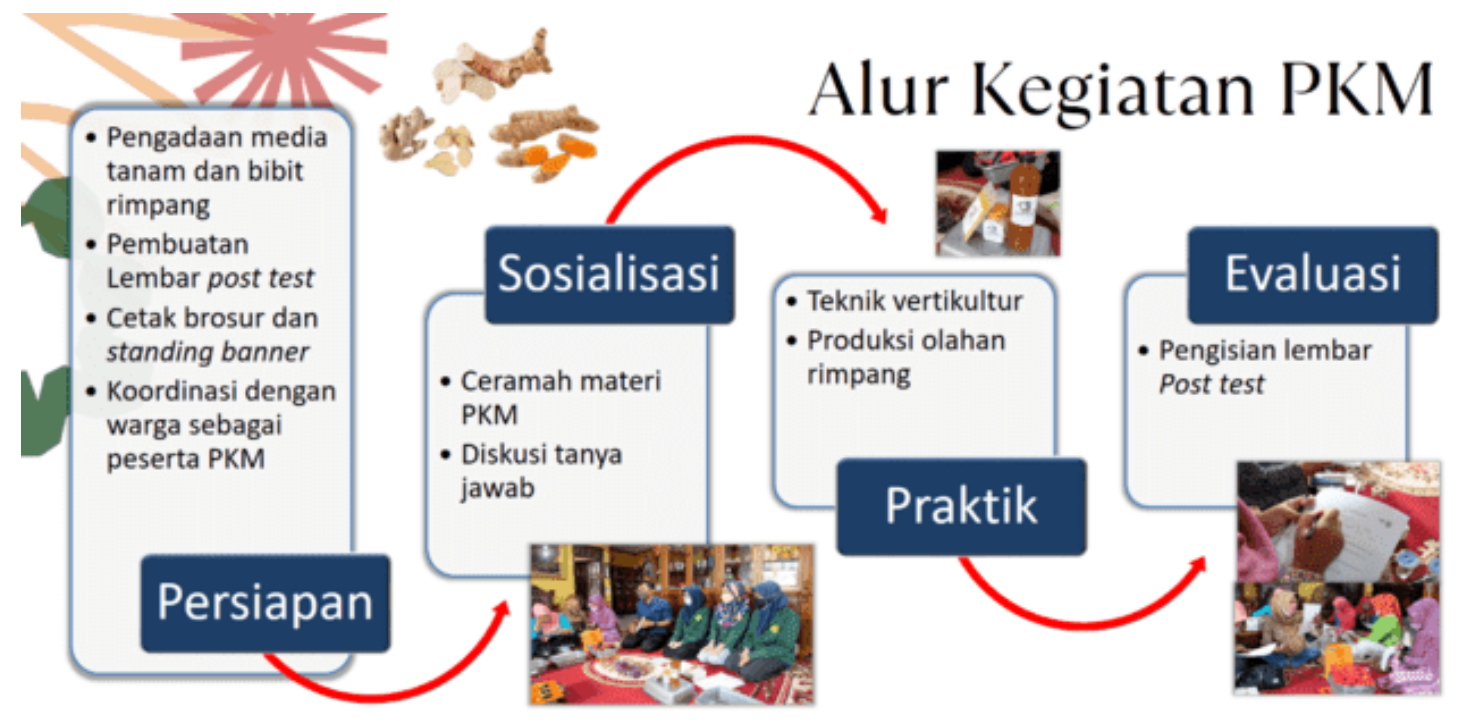

Gambar 1. Alur kegiatan PKM

\section{Metode Evaluasi}

Evaluasi tingkat kepahaman peserta terhadap pengetahuan dan kegiatan yang dilakukan diukur melalui metode post test. Prosedur post test adalah suatu evaluasi akhir dalam bentuk pertanyaan yang di berikan kepada masyarakat sasaran setelah materi telah tersampaikan dengan begitu dapat diperoleh gambaran tentang kemampuan yang dicapai setelah berakhirnya penyampaian materi. Kegiatan pengisian pertanyaan pada lembar post-test dilakukan setelah kegiatan sosialisasi, diskusi, dan demonstrasi praktik langsung. Peserta diminta untuk mengerjakan pertanyaan pada lembar post-test secara mandiri. Kegiatan PKM ini dikatakan berhasil jika menunjukkan rata-rata nilai post-test lebih dari 60 . Untuk kegiatan praktik budidaya tanaman rimpang melalui teknik vertikultur, evaluasi dilakukan mengacu pada penilaian kualitatif dengan memperhatikan indikator keberhasilan.

\section{HASIL DAN PEMBAHASAN}

Persiapan. Tahap persiapan dilakukan dengan menyiapkan media tanam yang akan digunakan dalam pembibitan tanaman rimpang. Terdapat beberapa jenis bibit rimpang yang digunakan dalam sosialisasi yaitu, jahe, kunyit, dan kencur. Persiapan lembar pertanyaan post test juga dilakukan pada tahap persiapan. Selain itu, penyiapan materi penyuluhan juga dilakukan pada tahap ini seperti cetak standing banner dan brosur (lihat lampiran). Selanjutnya koordinasi dengan warga sebagai peserta kegiatan PKM juga perlu dilakukan. Koordinasi dilakukan dengan perwakilan warga yaitu ketua RW 03 Kelurahan Rawamangun, Jakarta Timur. 
Sosialisasi. Alih teknologi yang dilakukan pada kegiatan ini dimulai dengan penyuluhan atau sosialisasi. Sosialisasi dimaksudkan untuk memberikan pengetahuan yang mencakup tiga materi yaitu: jenis dan karakteristik tanaman rimpang, cara budidaya tanaman rimpang dengan menggunakan teknik vertikultur, pengolahan hasil budidaya tanaman rimpang sebagai produk bernilai ekonomi tinggi, diantaranya bubuk rimpang, manisan rimpang, dan jamu. Kegiatan sosialisasi disampaikan melalui paparan oral dengan metode ceramah dengan peraga visual menggunakan standing banner dan brosur cetak yang telah dilengkapi oleh barcode yang terhubung dengan tautan video literasi di platform YouTube.
Pendekatan tersebut ditempuh untuk memudahkan adanya transfer ilmu pengetahuan. Pada saat sosialisasi dikembangkan kesempatan diskusi untuk memenuhi kebutuhan informasi para peserta. Peserta cukup antusias dalam mengajukan beberapa pertanyaan terkait pemanfaatan dan pemeliharaan tanaman rimpang hingga pengolahan produk tanaman rimpang. Beberapa peserta memiliki hobi bercocok tanam sehingga sudah pernah atau sedang memelihara tanaman rimpang, sedangkan beberapa peserta belum atau tidak pernah menanam tanaman rimpang sebelumnya, sehingga terjadi interaksi yang menarik diantara peserta. Dokumentasi kegiatan yang dilakukan dapat dilihat pada gambar 2 .

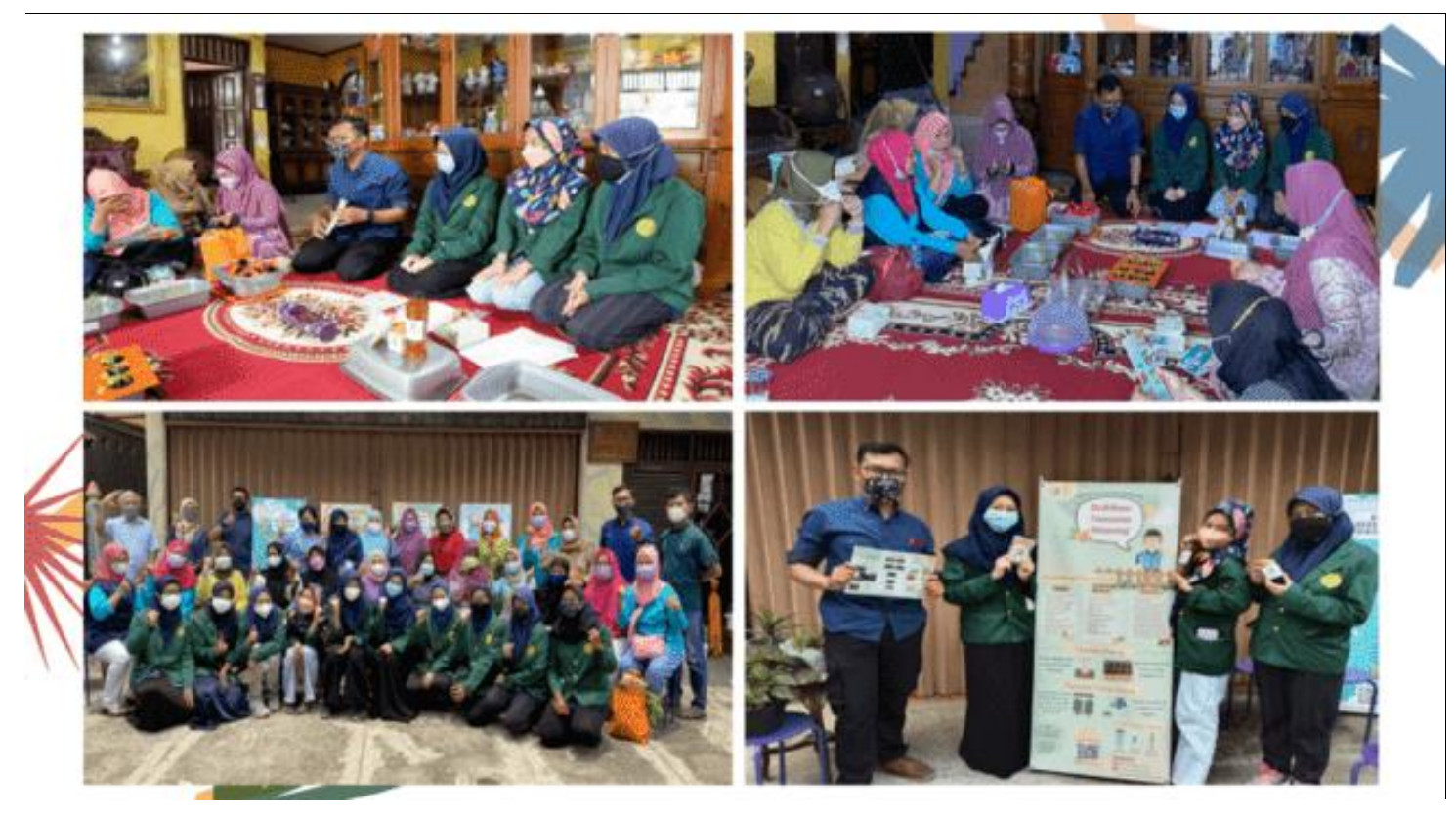

Gambar 2. Dokumentasi kegiatan PKM yang dilakukan di RW 03, Kelurahan Rawamangun, Kecamatan Pulogadung, Jakarta Timur.

Praktik Langsung. Kegiatan alih teknologi selanjutnya adalah demonstrasi praktik langsung budidaya tanaman rimpang. Para peserta sebagai 
khalayak sasaran dilibatkan langsung dalam tahapan budidaya tanaman rimpang. Tanaman rimpang yang ditanam meliputi jahe, kunyit, dan kencur. Tanaman rimpang seperti jahe, kunyit, dan kencur adalah contoh dari tanaman rimpang sekaligus tanaman obat keluarga yang mudah ditanam di pekarangan rumah dan dapat berguna sebagai pengusir berbagai penyakit ringan sehari-hari seperti batuk, masuk angin dan panas dalam. Rimpang dapat dikonsumsi langsung melalui metode seduh dengan air panas maupun dengan cara diolah terlebih dahulu menjadi produk lain. Dengan banyaknya khasiat yang ditawarkan oleh tanaman rimpang, diharapkan masyarakat dapat memetik manfaatnya sehingga dapat menuju masyarakat Indonesia yang sehat.

Keberhasilan Kegiatan. Perbedaan karakteristik peserta sesuai khalayak sasaran dapat dilihat pada tabel 1 .

Tabel 1. Karakteristik peserta pengabdian kepada masyarakat

\begin{tabular}{|c|c|}
\hline \multicolumn{2}{|c|}{ Karakteristik } \\
\hline $\begin{array}{l}\text { Jumlah } \\
\text { peserta }\end{array}$ & 12 orang \\
\hline $\begin{array}{l}\text { Tingkat } \\
\text { pendidikan }\end{array}$ & $\begin{array}{l}\text { SMA }=11(91,6 \%) \\
\text { Perguruan Tinggi }=1(8,3 \%)\end{array}$ \\
\hline Pekerjaan & $\begin{array}{l}\text { Ibu rumah tangga }=7(58,3 \%) \\
\text { Buruh }=4(33,3 \%) \\
\text { Pegawai kantoran }=1(8,3 \%)\end{array}$ \\
\hline Jenis & Perempuan = $12(100 \%)$ \\
\hline Kelamin & Laki-laki = $0(0 \%)$ \\
\hline
\end{tabular}

Situasi pandemi COVID-19 menyebabkan kegiatan pengabdian masyarakat ini menjadi terbatas. Sesuai peraturan pemerintah dalam kondisi PSBB (Pembatasan Sosial Berskala Besar) tidak diperkenankan untuk membuat forum besar. Sehingga dalam pelaksanaan program pengabdian masyarakat ini hanya dihadiri oleh 12 orang peserta. Jenis kelamin dari peserta yang mengikuti kegiatan pengabdian ini seluruhnya adalah perempuan. Hal tersebut berkaitan dengan topik materi yang dibahas pada kegiatan PKM ini yaitu pemanfaatan tanaman rimpang yang identik dengan bumbu dapur, sehingga bukan hal yang luar biasa jika peserta yang hadir seluruhnya adalah berjenis kelamin perempuan. Tingkat pendidikan dari kedua kelompok peserta penyuluhan tertinggi lulusan SMA dengan pekerjaan sebagai ibu rumah tangga. Hal ini sesuai dengan target dari kegiatan PKM yaitu terciptanya kegiatan positif dan produktif yang dapat dilakukan oleh warga yang dapat memanfaatkan waktu senggangnya untuk budidaya tanaman rimpang di halaman/pekarangan rumah masingmasing. Partisipasi peserta terhadap kegiatan PKM tergolong baik yang ditunjukkan dengan kehadiran dan 
antusias peserta mengikuti keseluruhan acara hingga acara berakhir sehingga tujuan kegiatan PKM juga tercapai.

Kebermanfaatan dan tingkat penerimaan peserta terhadap pengetahuan dan teknik yang diberikan dapat dievaluasi menggunakan metode post test. Metode ini juga dilakukan oleh Hadi et al. (2017) yang mengemukakan bahwa penerapan teknik budidaya dan edukasi beragam jenis sayur dan manfaatnya dapat dilaksanakan dengan baik dan menunjukkan hasil yang baik ditinjau dari hasil post test. Dokumentasi kegiatan pengerjaan post test sebagai evaluasi pengetahuan terhadap materi yang telah disampaikan yang selanjutnya dapat dilihat pada gambar 3 .

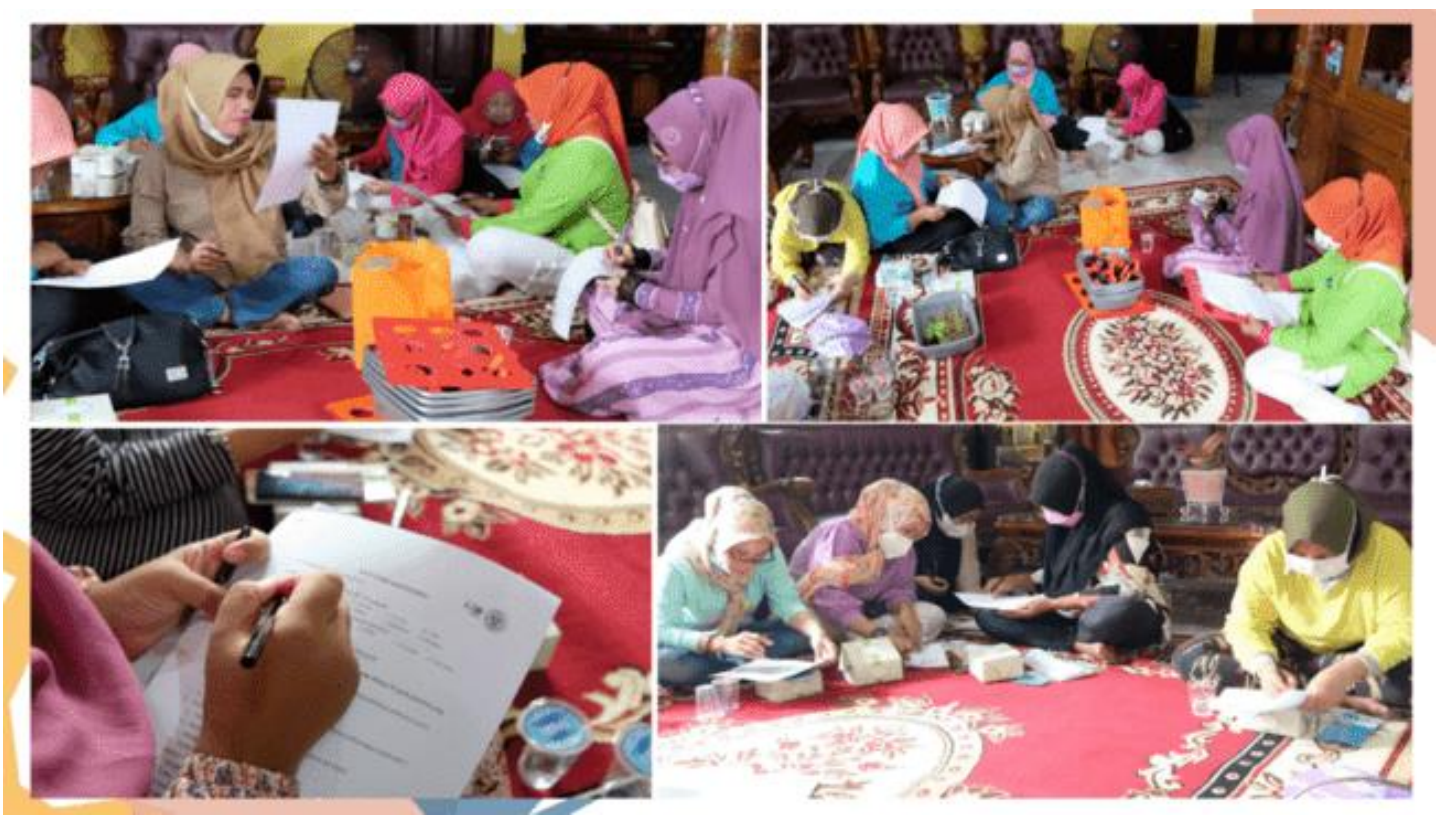

Gambar 3. Pengerjaan test sebagai evaluasi pengetahuan terhadap materi

Hasil post test yang telah dilakukan setelah adanya penyuluhan menunjukkan terjadi peningkatan pengetahuan atau pemahaman peserta penyuluhan terutama mengenai ilmu budidaya tanaman rimpang dengan teknik vertikultur serta pengolahan produk rimpang menjadi produk yang bernilai jual tinggi. Kegiatan pengabdian ini tergolong berhasil karena hasil post test menunjukkan nilai rata-rata lebih dari 60 yaitu nilai rata-rata post-test 70 . Selanjutnya grafik nilai post test setiap peserta ditampilkan pada gambar 4 . 


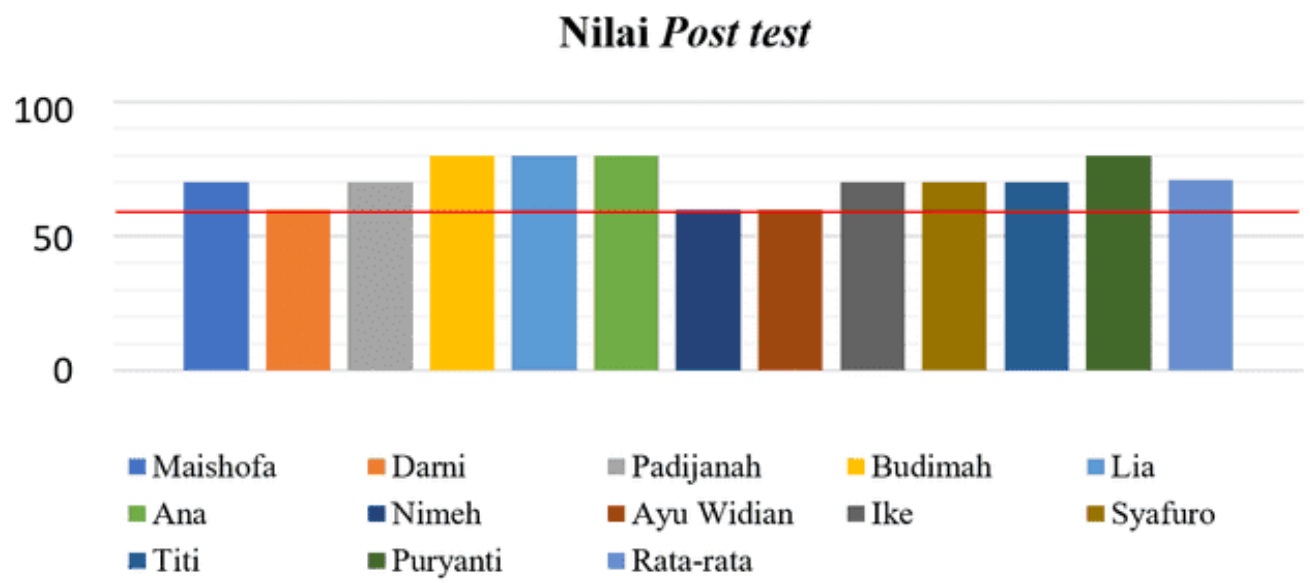

Gambar 4. Hasil Penilaian Post test

Seluruh peserta menunjukkan antusiasme yang tinggi dalam melakukan serangkaian kegiatan PKM mulai dari pembuatan media tanam, penanaman, dan pemeliharaan tanaman rimpang di lahan pekarangan masingmasing. Rangkaian kegiatan PKM yang dilakukan sebagai upaya meningkatkan keterampilan dan ketertarikan para warga untuk mencoba melakukan budidaya tanaman rimpang di halaman rumah masing-masing menggunakan metode vertikultur. Jenis ini dipilih karena memiliki tujuan dan manfaat yang jelas, bentuk kegiatan sederhana, dan dapat diterapkan di pekarangan masing-masing setiap saat, dan memiliki prospek yang baik untuk membuka peluang bisnis melalui produksi hasil budidaya tanaman rimpang dengan produk yang bernilai jual tinggi. Terdapat tiga produk yang diperkenalkan kepada peserta yaitu serbuk rimpang, manisan rimpang dan jamu. Produk-produk tersebut dibuat agar siap untuk dikonsumsi dan selanjutnya dikemas rapih dalam kemasan plastik yang disesuaikan dengan jenis produk masing-masing. Produk serbuk rimpang dikemas dalam kantung plastik bersegel. Produk manisan rimpang dikemas dalam toples plastik mini. Produk jamu dikemas dalam botol plastik kecil dengan desain kekinian. Selanjutnya, semua kemasan produk ditempel dengan stiker branding produk sehingga siap untuk dipasarkan. Produk olahan rimpang dari hasil budidaya tanaman rimpang dapat dilihat pada gambar 4.

Seluruh dokumentasi kegiatan PKM baik foto dan video ditayangkan di media sosial YouTube. Diharapkan dokumentasi kegiatan PKM tersebut dapat dimanfaatkan oleh masyarakat dengan jangkauan yang lebih luas. Cuplikan media sosial YouTube sebagai bentuk publikasi kegiatan PKM dapat dilihat pada gambar 5 . 

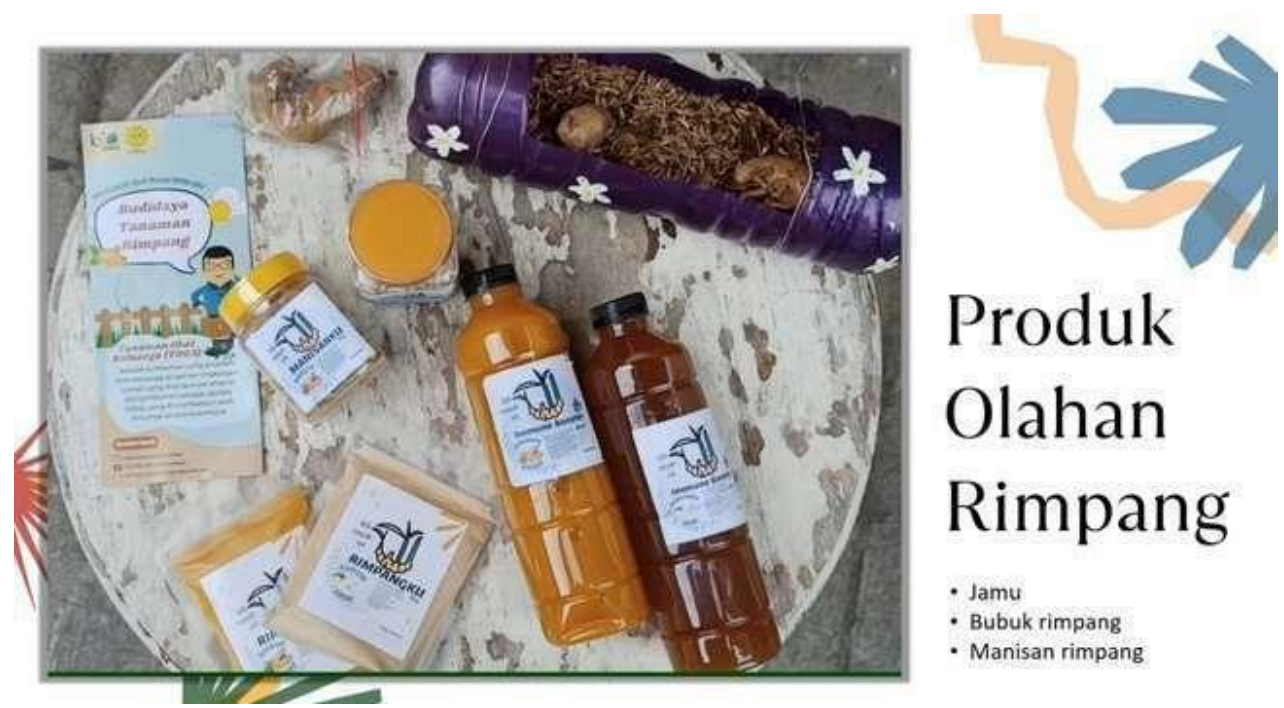

Gambar 4. Branding produk olahan rimpang

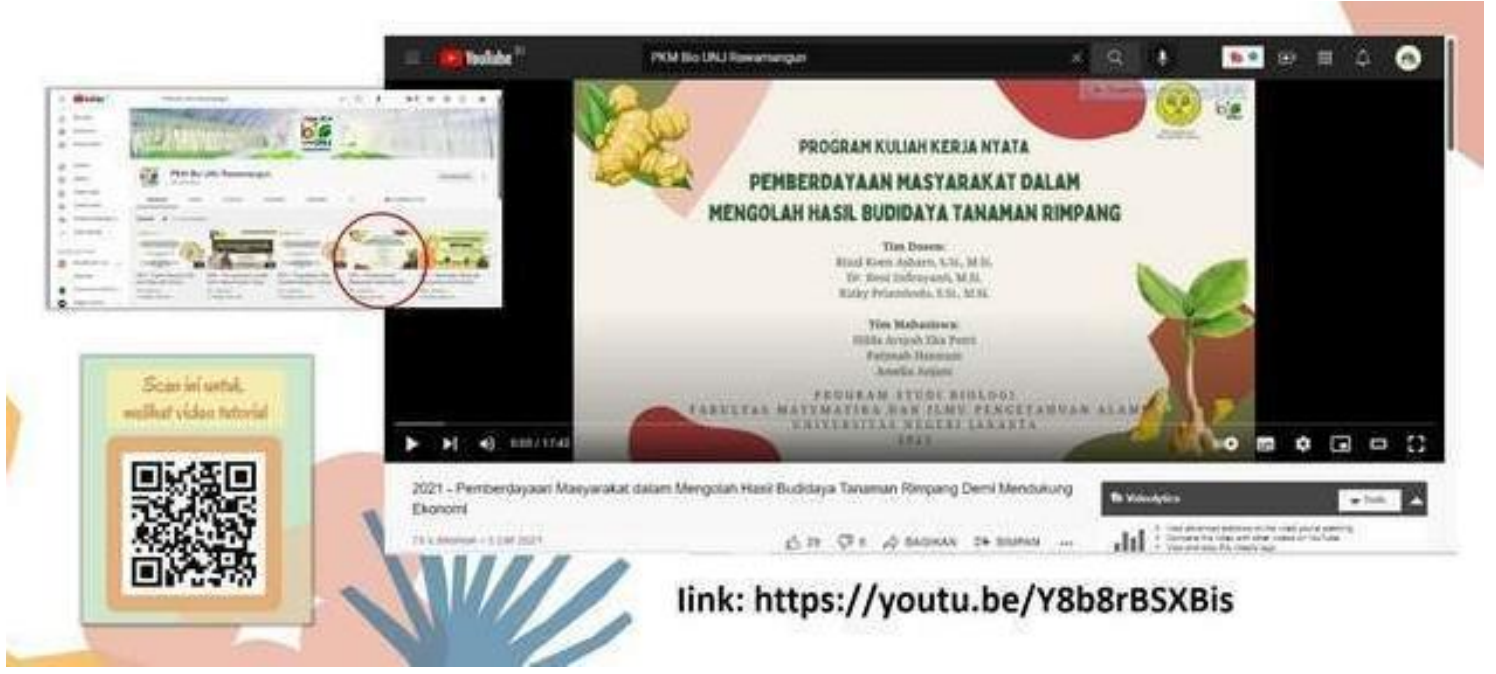

Gambar 5. Cuplikan dokumentasi kegiatan PKM di YouTube

\section{PENUTUP}

Hasil pelaksanaan rangkaian kegiatan PKM ini menunjukkan bahwa peserta sangat antusias dalam mengikuti seluruh kegiatan. Peserta kegiatan sudah memiliki pengetahuan dasar mengenai jenis-jenis, manfaat, dan teknik budidaya tanaman rimpang tetapi masih terbatas. Evaluasi keberhasilan program dilakukan dengan post test kepada peserta setelah dilakukan ceramah, diskusi, dan praktik. Program ini tergolong berhasil karena adanya peningkatan pengetahuan dasar mengenai teknik budidaya tanaman rimpang dengan nilai post test di atas 60 dan kegiatan praktik berlangsung dengan baik. Pengolahan hasil budidaya tanaman rimpang menjadi produk bernilai ekonomi tinggi seperti bubuk rimpang, manisan rimpang, dan jamu juga berhasil dilakukan. Seluruh peserta menunjukkan antusiasme yang tinggi pada saat melakukan praktik langsung. 
Diharapkan hasil olahan budidaya tanaman rimpang dapat dikomersilkan sehingga dapat mendukung sistem perekonomian masyarakat

Rawamangun.

\section{DAFTAR PUSTAKA}

Asharo, R.K., Lisanti, E., Indrayanti, R., Adisyahputra, Pasaribu, P.O., Priambodo, R., Rizkawati, V., Irnidayanti, Y. 2021. Cultivation of Family Medicinal Plants using the Verticulture Method as Efforts to Use Narrow Yard Land in Rawamangun, East Jakarta. Jurnal Pemberdayaan Masyarakat Madani, 5 (1): 61-74.

Departemen Pertanian RI. 2007. Prospek dan Arah Pengembangan Agribisnis Tanaman Obat Edisi Kedua.

Hadi, S.N., A.Y. Rahayu, I. Widiyawati. 2017. Penerapan Teknologi Berkebun Sayur secara Vertikultur pada Siswa Sekolah Dasar di Purwokerto, Jawa Tengah. Jurnal Panrita Abdi, 1 (2): 114-119.

Harefah, D. 2020. Pemanfaatan Hasil Tanaman Sebagai Tanaman Obat Keluarga (TOGA). Madani : Indonesian Journal of Civil Society, 2 (2): 28-36.

Hernani, Winarti. 2011. Kandungan Bahan Aktif Jahe dan Pemanfaatannya dalam Bidang Kesehatan. Balai Besar Penelitian dan Pengembangan Pascapanen Pertanian, Bogor.

Kandari, L.S., Phondani, P.C., Payal, K.C. Rao, K.S., Maikhuri, R.K. 2012. Etnobotani Study toward
Conservation of Medicinal and Aromatic Plant in Upper Catchments of Dhauli Ganga in the Central Himalaya. Jurnal of Mountain Science, 9: 286-296.

Marlinah, L. Meningkatkan Ketahanan Ekonomi Nasional Melalui Pengembangan Ekonomi Kreatif. Cakrawala. XVII (2): 2579-3314.

Nurmayulis, Hermita, N. 2015. Potensi Tumbuhan Obat dalam Upaya Pemanfaatan Lahan Pekarangan Oleh Masyarakat Desa Cimenteng Kawasan Taman Nasional Ujung Kulon. Jurnal Agrologia, 4 (1): 17.

Palupi, M.R., Widyaningsih, T.D. 2015. Pembuatan Minuman Fungsional Liang Teh Daun Salam (Eugenia polyantha) dengan Penambahan Filtrat Jahe dan Filtrat Kayu Secang. Jurnal Pangan dan Agroindustri. 3 (4) : 1458 - 1464.

Pasaribu, P.O., Indrayanti, R., Adisyahputra, Asharo, R.K., Priambodo, R., Rizkawati, V., Irnidayanti, Y. 2020. Pelatihan Budidaya Pakcoy dengan Sistem Hidroponik Rakit Apung sebagai Upaya Memanfaatkan Pekarangan Sempit di Rawamangun, Jakarta Timur. Prosiding Seminar Nasional Pengabdian kepada Masyarakat 2020 (SNPPM-2020): 108-118.

Rauf, A., Rahmawaty, Budiati, D. 2013. Sistem Pertanian Terpadu di Lahan Pekarangan Mendukung Ketahanan Pangan Berkelanjutan dan Berwawasan Lingkungan. 
Jurnal Online Pertanian Tropik Pasca Sarjana FP USU, 1 (1): 1-8. Saktiawan, R.A., Atmiarsi. 2017. Pemanfaatan Tanaman Toga bagi Kesehatan Keluarga dan Masyarakat. Abadimas Adi Buana, 2 (2): 57-64.

Shan, C.Y., Iskandar, Y. 2018. Studi Kandungan Kimia Dan Aktivitas Farmakologi Tanaman Kunyit (Curcuma longa L.). Farmaka, 16 (2): 547-555.
Suryani, Nurjasmi, R., Sholihah, S.M., Kusuma, A.V.C. 2017. Pelatihan Pertanian Perkotaan. Jurnal Pelayanan dan Pengabdian Masyarakat, 1(1), 69-81.

Syarif, P., Suryotomo, B., Soeprapto, H. 2011. Diskripsi dan Manfaat Tanaman Obat di Pedesaan, Sebagai Upaya Pemberdayaan Apotik Hidup (Studi Kasus di Kecamatan Wonokerto). Pena: Jurnal Ilmu Pengetahuan dan Teknologi, 21 (1): 20-32. 